\title{
脳室,クモ膜下腔灌流実験による中枢神経 系に関する薬理学的研究(第相報)
}

特に諸種薬物の灌流液排出量と血圧に及

将す影響について

平島毅

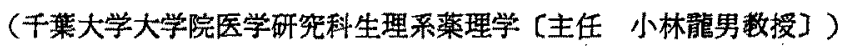

（昭和37年 1 月18日受付[特]）

\section{はじめに}

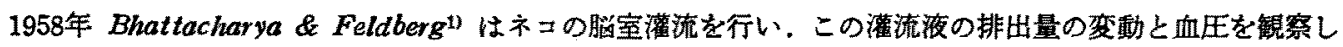
つつ Tubocurarine, Histamine, Adrenaline を静注したところ Cisterna からの集液には血圧の変動と関連 して大きな变化があったのに対し，Aqueduct からの集液には何らの変化も起らなかったことから前者の結果

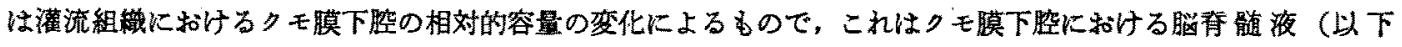
c.s.f. と略す）の生成，血王媨血流量から㷌結されるクモ膜下腔の容量. 或いは脳膜血管透過性などの変化火基

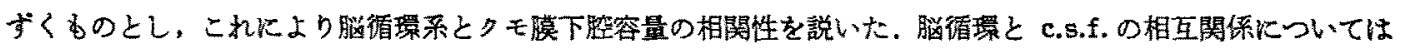

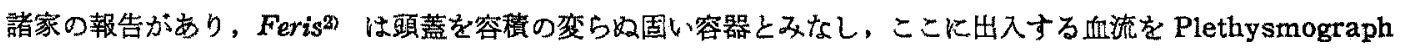
法によって測定せんとし，Gregg \& Shipleys) は実际には多くの硬膜下腔静脈の影響を受けるので注射針を

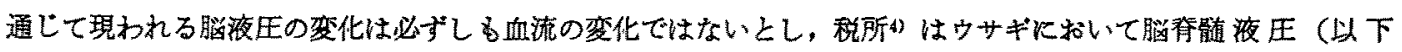
c.s.p. と略す）と脳血流々関倸があることを菜理学的に証明し, 腷王上身の度は脳血流增大の度と比例して現わ

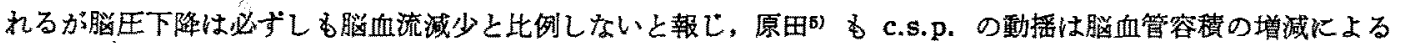

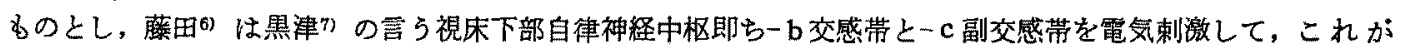
興桷と c.s.p. の相関性汇ついて報告した。

一方 Weed \& Cushing $^{8)}$, Dixon \& Halliburton ${ }^{9}$ 及び Woollam \& Millen ${ }^{10)}$ らは c.s.p の動播は c.s.f. の産生, 再吸収の变動と関保があるとした。

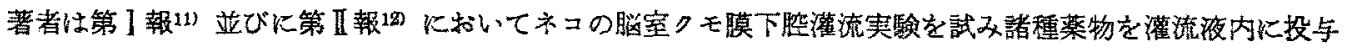
して呼吸及び血圧に和よぼす㚆動を観察する万法を確立し，これについての実験を詳細に亘り報告した，その祭 脳室クモ膜下腔を灌流（C法）した時も，側脳室第三脳室を限局的に灌流（A法）した时もChlorpromazine， Perphenazine, Hydroxyzine, Thiopental sodium, Caffeine 及び高張食塩水の灌流液内投与では滴数の增

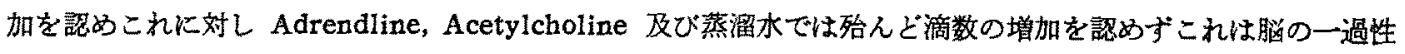
の浮腫または腫張に基ずく物理的な浸透压，透析または沪出などよると考えた。

このよ5K c.s.p. の変動には呼吸, 血圧, 脂膜血管压, 更には c.s.f. の産生, 透析, 分泌, 汇出及び再吸 収など種々の要因が関与するよらに考えられるもので著者はさらに第I報11 の脳空クモ膜下腔灌流法にしたが い $d$-Tubocurarine chloride, Adrenaline, Acetytcholine, Histamine, Caffene 及び Chlorpromazine どを体部堘眽内に注射した漈の满流液排出の態度について梌索を行った。

\section{实馀方法及び材料}

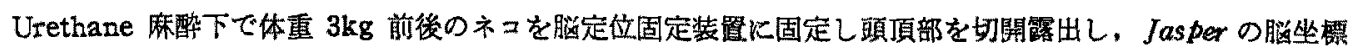
図13) に従いFr $12.0 \mathrm{~mm}$, Lat $4.0 \mathrm{~mm}$ の位置に直径 $1.5 \mathrm{~mm}$ の穴を開け, 内径 $1 \mathrm{~mm}$, 長さ $15 \mathrm{~cm}$ の透明な Polyethylene 管に鉄製マンドリンをつけ、これを梁さ $+7.5 \mathrm{~mm}$ の位固より側脑室内に捙入してこれを齿口科 
用セメントで固定し，酸素飽和 Locke 液を $38^{\circ} \mathrm{C}$ の恒温槽を通し定圧自動注入器を用いて脳室内を灌流した。 灌流液の排出は小脳延蹃槽内にあらかじめ穿刺しておいた静脈注射を通じて行う〔脳室クモ膜下胫灌流 : (C)

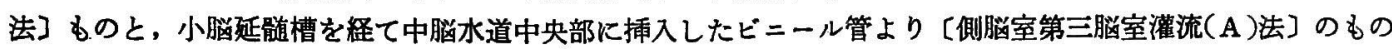
との二法とした，灌流液排出は滴数計をもって測定し，また同時に股動哌圧曲線を煤紙上に描記した。 あらかじ め露出した左伏在静脈または股静脈より薬液 $1.0 \mathrm{cc}$ を $20^{s}$ 前後の速度で注射した. なお，脳室灌流速度は 0.11 $6 \mathrm{cc} / \mathrm{min}$ とし，体動及び呼吸の影響をなくする為に $d$-Tubocurarine chloride $0.5 \mathrm{mg} / \mathrm{kg}$ を適時注射し人工 呼吸下で実験した.

試用した薬物は $d$-Tubocurarine chloride (Lilly, Amelizol), Adrenaline chloride, Acetylcholine chloride, Histamine dihydrochloride, Caffeine sodio-benzoate, Chlorpromazine を用いた.

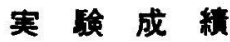

\section{1. d-Tubocurarine chloride の排出洨声数ならびに血压に及任す影斐}

（1）（C）法による場合

$d$-Tubocurarine chloride (以下 d-Tc.) $1 \mathrm{mg} / \mathrm{kg}$ では注射直後より不定の血圧下降を呈し $2^{\mathrm{m}}$ 後には $60 \mathrm{mmHg}$ の下降を示し, これに平行して排出液滴数を著明に増量を示したが $2^{\mathrm{m}}$ 後呼吸停止を認めたので人口 呼吸を開始したところ直ちに这射前の滴数に復した。（第 1 図）

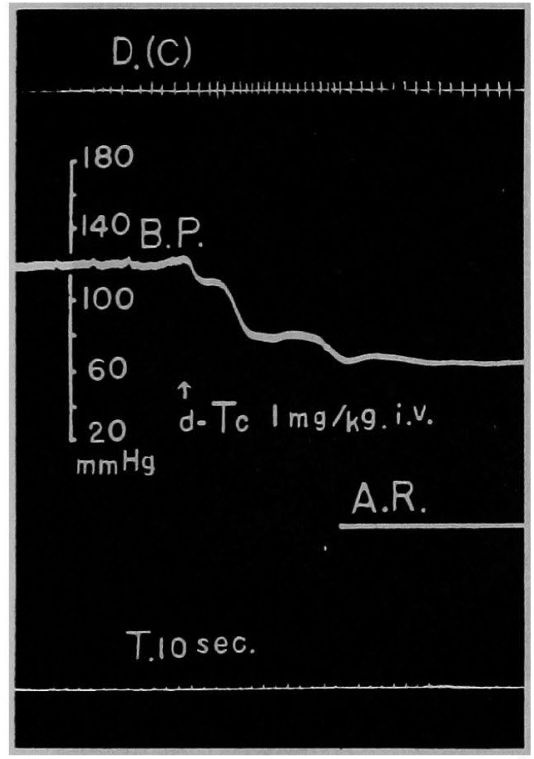

第 1 図.（C）法に拈ける $d$.Tc (1mg/ $\mathrm{kg}$ 股静脈注射）の排出液滴数, 血圧に対する作用. 上段：滴数, 下段 : 血圧, A.R. : 人工呼吸 時㮮 $10^{4}$

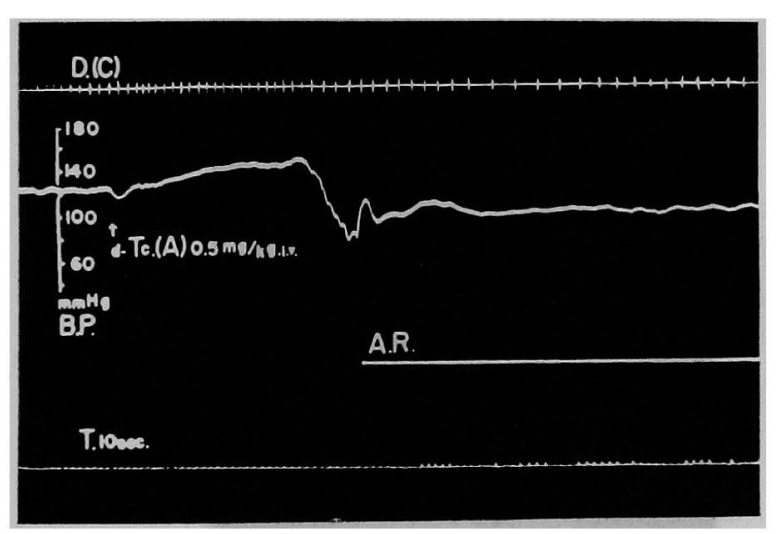

第 2 図.（C）法に批る $d$-Tc (Amelizol $0.5 \mathrm{mg} / \mathrm{kg}$ 股静脈注射) の排出液滴数, 血圧に対する作用。 上段 : 滴数, 下 : 股動脈圧, A.R. : 人工呼吸, 時標 $10^{\mathrm{s}}$

$0.5 \mathrm{mg} / \mathrm{kg}$ 股静脈内注射では直後より不定の血圧上界の後下降を示し $5^{\mathrm{m}}$ 後には $40 \sim 50 \mathrm{mmHg}$ の下降を 示し呼吸停止を来たしたので人工呼吸を開始した。この間排出液滴数は持続的な著明な增加を示したが $4^{\mathrm{m}}$ で次 第に液滴数の間隔が增し, 人工呼吸開始 $3^{\mathrm{m}}$ 後には最大間隔を示し以後次第に間隔がせまくなり $15^{\mathrm{m}}$ 後投与前 の状態に戻った.（2因）

人工呼吸下で $0.5 \mathrm{mg} / \mathrm{kg}$ 股静脈内注射 $10^{\mathrm{m}}$ または $20^{\mathrm{m}}$ 後に再び $d-\mathrm{Tc} 0.5 \mathrm{mg} / \mathrm{kg}$ を注射すると滴数は著 明な增减を示さなかった.つぎに $d-\mathrm{Tc}$ 注射前 $2^{\mathrm{m}} 30^{\mathrm{s}}$ に人工呼吸をあらかじめ開始した場合には, 血圧は僅 
かに上年の傾向をみとめ排出液は一過性の動摇を示したが以後変動を示さず血压は $20 \mathrm{mmHg}$ の下降後次第に恢 復した。

即ち $d$-Tc 静注により血压は一過性の上界後下降を示すが動摇を示し易く，また排出液は血圧の変動とほぼ 一致して增減するが, 人工呼吸を行うことによって規則的となり，あらかじめ人工呼吸を施行しつつ $d-\mathrm{Tc}$ を注 射すれば排出液滴数の変動は殆んどみられなくなる。

(ii) (A). 法に上る場合

$d$-Tc $0.5 \mathrm{mg} / \mathrm{kg}$ 静注では直後一過性の血压上界を呈したのち $2^{\mathrm{m}}$ には $50 \mathrm{mmHg}$ 下降して呼吸停止をきた したので人工呼吸を開始したが，滴数には全く変化を認めなかった。（3図）

\section{Adrenaline の排出液滴数ならびに血圧に及ぼす影響}

（i）（C）法による場合

Adrenaline (以下 Ad と略す) $7 \mathrm{fg} / \mathrm{kg}$ 静注直後の血圧上年に一致して一過性に湳数が增し血圧が最高を 過ぎるあたりから下降するむでば液滴数の閒隔が開いたが血圧が正常に戻るにつれ旧に復した． $10 \mu \mathrm{g} / \mathrm{kg}$. 静注 の場合でも直後血圧の急騰するにつれて滴数は著明に增加し血圧が最高値澾した頃より間隔が開きはじめ, 血 圧の下降漈し滴数の最大間隔が 40 をを示すこともあるが血圧の正常化とともに旧に復した。（4図）

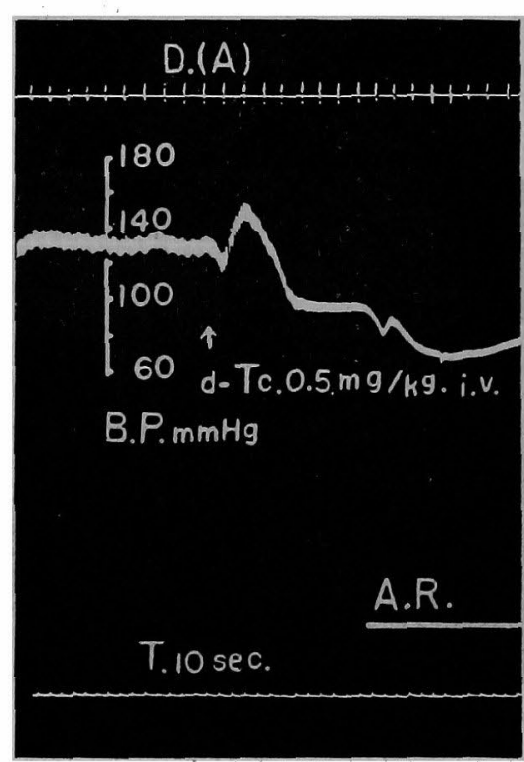

第 3 図.（A）法氾おる $d-\mathrm{Tc}(0.5 \mathrm{mg} / \mathrm{kg}$ 股静脈注射) の排出液滴数, 血圧に 対する作用. 上段 : 滴数, 下: 股動 眽圧, A.R. : 人工呼吸, 時標 $10^{\mathrm{s}}$

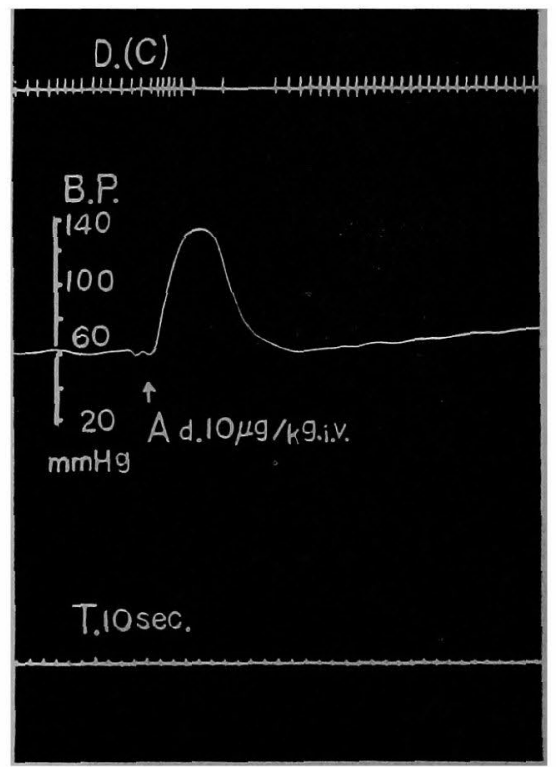

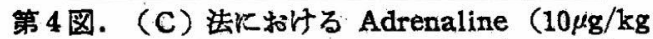
股静脈注射) の排出液滴数, 血正に対す る作用. 上段 : 滴数, 下段 : 股動脈圧, 時標 $10^{9}$

\section{（ii）（A）法による場合}

Ad $7 \mu \mathrm{g} / \mathrm{kg}, 10 \mu \mathrm{g} / \mathrm{kg}$ で血圧は Ad. 特有な上年に続く下降の曲線を呈したが, 滴数には変化を認めなかっ た.

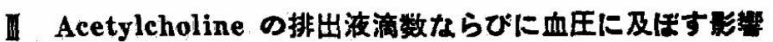

(i) (C) 法に上る場合

Acetylcholine (以下 ACh. と略す) $7 \mu \mathrm{g} / \mathrm{kg}$ 静注直後から血仕は約 $60 \mathrm{mmHg}$ の著明な下降を示したが, 一方排出液滴数は直ちに增加を示し衈圧が次第に恢復して行くにつれて旧に復した。

$10 \mu \mathrm{g} / \mathrm{kg}$ では血圧は約 $100 \mathrm{mmHg}$ 程急下降を示したが滴数は直ちに增加し, これが $1^{\mathrm{m}}$ 持続した後逆に 
間隔が開いたのち旧に復した。（6 図）

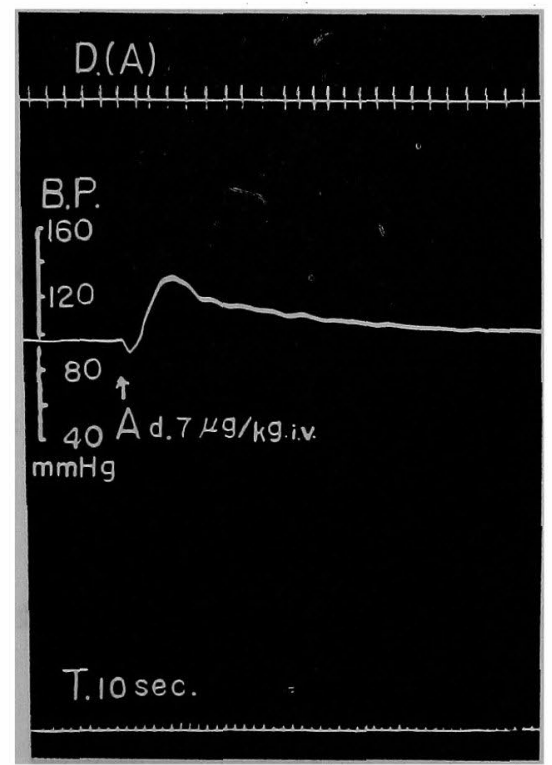

第5図.（A）法に和们る Adrenaline $(7 \mu \mathrm{g} / \mathrm{kg}$ 股静脈注射) の排出液 滴数, 血压に対する作用. 上段 : 滴数, 下段 : 股動脈圧, 時標 $10^{5}$

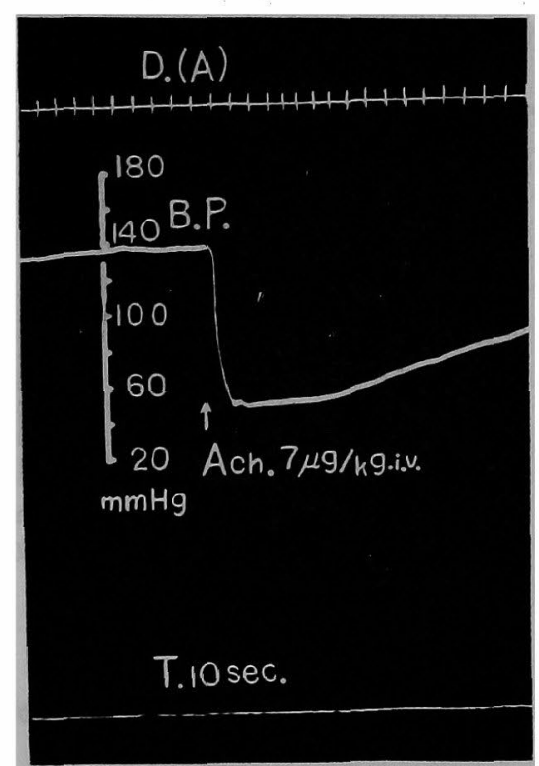

第 7図.（A）法に招ける Acetylcholine $(7 \mu \mathrm{g} / \mathrm{kg}$ 股静脈注射) の排出液 滴数, 血圧に対する作用. 上段： 滴数, 下段：股動脈圧, 時標 $10^{\mathrm{s}}$

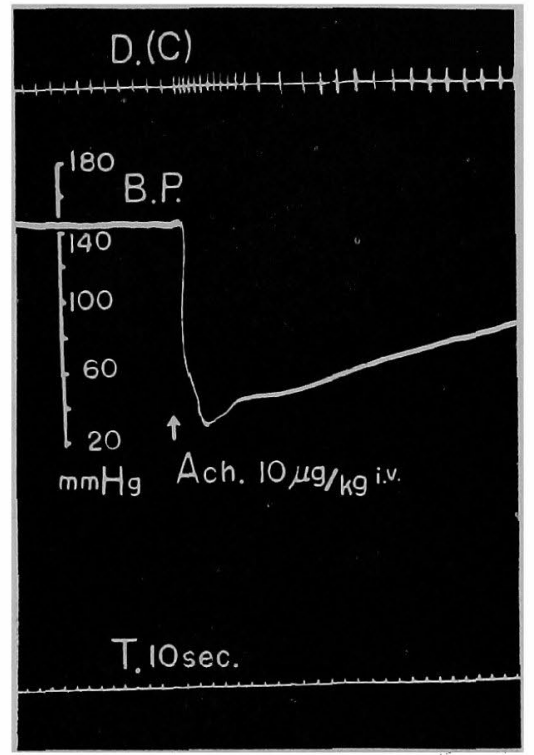

第6図. (C) 法に批ける Acetylcholine $(10 \mu \mathrm{g} / \mathrm{kg}$ 股静脈注射) の排出 液滴数, 血圧に対する作用. 上段 : 滴数, 下段 : 股動脈圧, 時標 $10^{\mathrm{s}}$

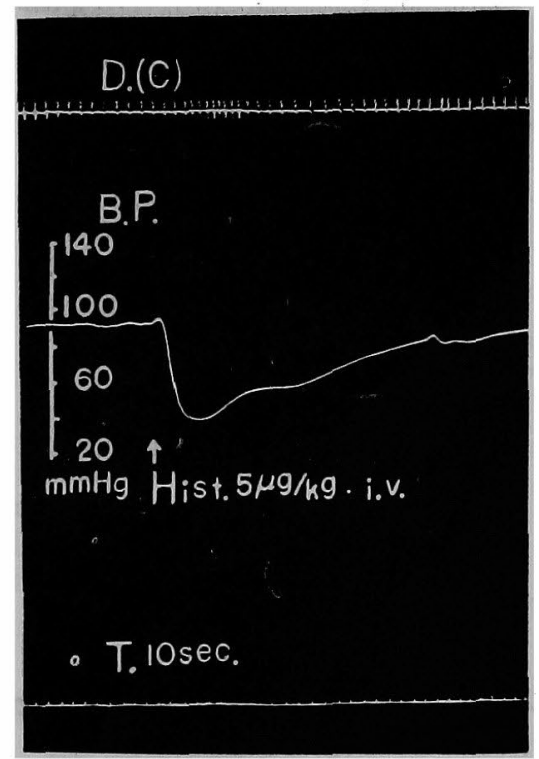

第8図.（C）法に打ける Histamine $(5 \mu \mathrm{g} / \mathrm{kg}$ 股静脈注射)の排出液滴 数, 血圧に対する作用. 上段 : 滴 数, 下段 : 股動脈压, 時標 $10^{\mathrm{s}}$ 
（ii）（A）法による場合

Ach $7 \mu \mathrm{g} / \mathrm{kg}, 10 \mu \mathrm{g} / \mathrm{kg}$ 静注直後より血圧は著明な下降を示したが滴数には殆んど変化を認めなかった。 ( 7 図)

\section{Histamine の排出液滴数ならびに血圧に及ぼす影響}

(i) (C) 法による場合

Histamine (以下 Hist. と略す) $5 \mu \mathrm{g} / \mathrm{kg}$ 静注後直ちに血厈は下降し滴数は次第に增加し，血圧が $40^{\mathrm{s}}$ で $50 \mathrm{mmHg}$ の最近値を示した時に最も多く，血圧の恢復にともなって泍次正常にかえった。（因 8 ）

$10 \mu \mathrm{g} / \mathrm{kg}$ 静注後直ちに血圧は $50 \sim 60 \mathrm{mmHg}$ の下降を示乙, 滴数は約 $40 \sim 50^{4}$ 後に最も多く, 血压の恢復 にともなって漸次正常となった.

（ii）（A）法による場合

Hișt. $5 \mu \mathrm{g} / \mathrm{kg}, 10 \mu \mathrm{g} / \mathrm{kg}$ 静注で血圧は前述の如く著明な下降を示したが, 滴数には変化が認められなかっ た. ( 9 図)

V Caffeine sod. benz. の排出液滴数ならびに血圧に及ぼす影響

(i) （C）法炕よる場合

Caffeine (以下 Caff. と略す) $40 \mathrm{mg} / \mathrm{kg}$ を注射すると血压は約 $100 \mathrm{mmHg}$ 下降し，この間排出液滴数は著 明に增加するが血圧が次第に恢復するにつれて間隔が開くことなく漸次旧に復した（10因）

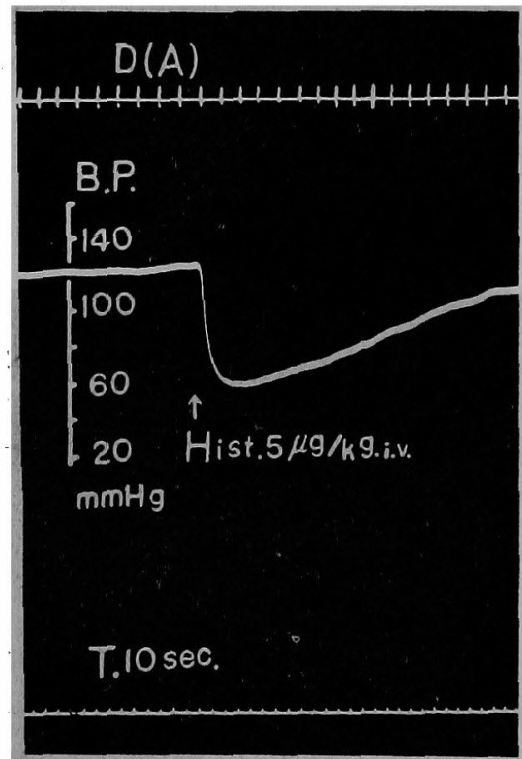

第9図.（A）法に括ける Histamine $(5 \mu \mathrm{g} / \mathrm{kg}$ 股静脈注射) の排出液滴 数, 血圧に対する作用. 上段 : 滴 数, 下段 : 股動脈圧, 時標 $10^{\text {s }}$

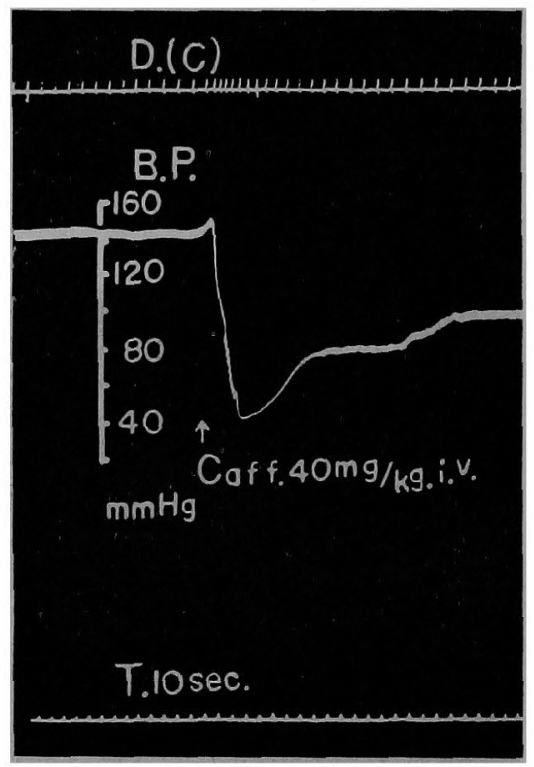

第10図.（C）法に批る Caffeine (40m $\mathrm{g} / \mathrm{kg}$ 股静脈注指) の排出液滴数, 血圧に対する作用. 上段 : 滴数, 下段：股動脈圧, 時標 $10^{s}$

$50 \mathrm{mg} / \mathrm{kg}$ でも同様血王下降と同期して滴数は直らに著明なる堌加を呈し，血厌の恢復につれて間隔が開く ことなく濑次もとに復した。

（ii）（A）法による場合

Caff. $40 \mathrm{mg} / \mathrm{kg}$ 静注で血压は約 $60 \sim 70 \mathrm{mmHg}$ の下降を呈したが排出液滴数には何らの变化も認められなか った (11図) . 


\section{Chlorpromazine の排出液滴数と血圧に及ぼす影響}

(i) (C) 法に上る場合

Chlorpromazine (以下 Cp. と略す) $0.1 \mathrm{mg} / \mathrm{kg}, 0.2 \mathrm{mg} / \mathrm{kg}, 0.5 \mathrm{mg} / \mathrm{kg}$ 及び $1 \mathrm{mg} / \mathrm{kg}$ の少量の静注では約

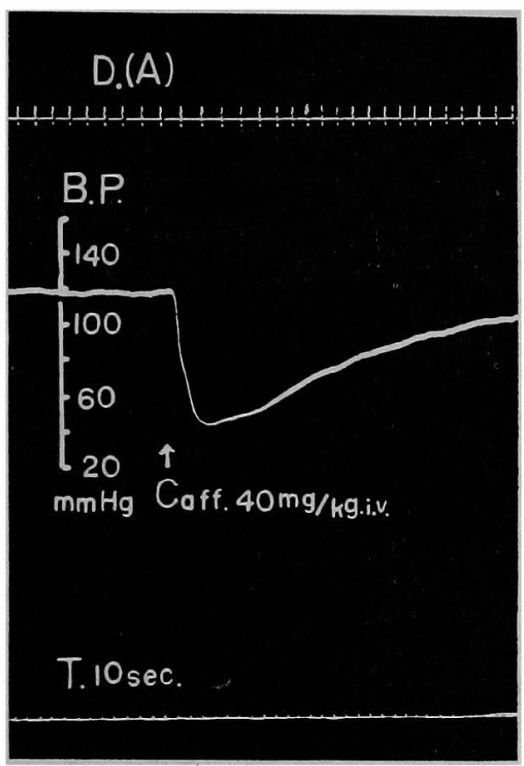

第11図.（A）法沉おける Caffeine (40m $\mathrm{g} / \mathrm{kg}$ 股静脈注射) の排出液滴数, 血压に対する作用. 上段 : 滴数, 下段：股動脈圧, 時標 $10^{\text {s }}$

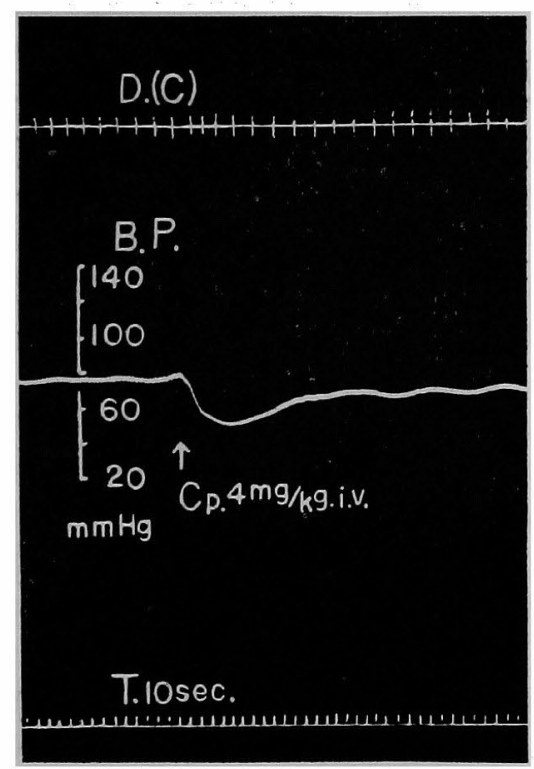

第13図.（C）法に扑ける Chlorpromazine $(4 \mathrm{mg} / \mathrm{kg}$ 没静脈注射) の排出液 滴数, 血压に対する作用. 上段 : 滴数,下段：股動脈圧, 時楅 $10^{\mathrm{s}}$

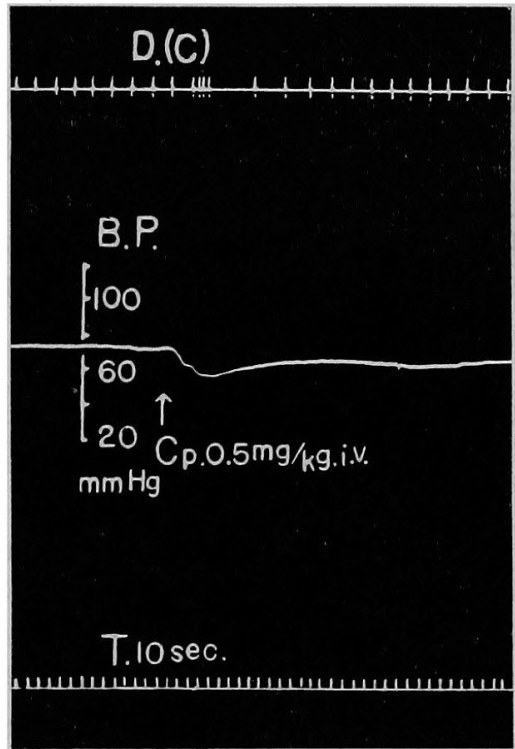

第12図.（C）法に括ける Chlorpromazine? $(0.5 \mathrm{mg} / \mathrm{kg}$ 、股静脈注射) の排出 液滴数, 血圧に対する作用. 上段 : 滴数, 下段 : 股動脈圧, 時標 $10^{\mathrm{s}}$

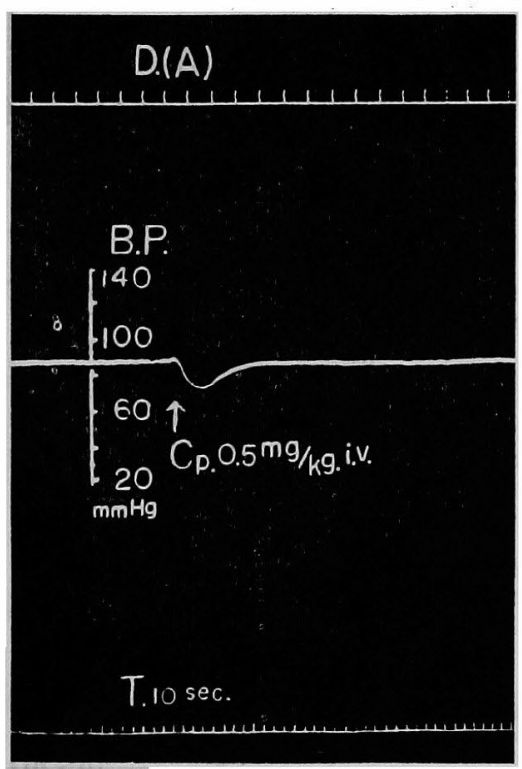

第14図.（A）法における Chlorpromazine $(0.5 \mathrm{mg} / \mathrm{kg}$ 股静脈注射) の排出 液滴数, 血圧に対する作用. 上段 : 滴数, 下段：股動脈圧, 時標 $10^{\mathrm{s}}$ 
$20 \mathrm{mmHg}$ の血圧下降を示したが排出液滴数は一過性の增加を呈したのち直ちに間隔が延長し，注射後 2〜3 元に芦った.（12図）

$2 \mathrm{mg} / \mathrm{kg}, 4 \mathrm{mg} / \mathrm{kg}$ 静注では血王は約 $20 \sim 30 \mathrm{mmHg}$ の下降を示したが排出液には特に著明な变化を認めな かっ大，(13図）

(ii) (A) 法に上万場合

Cp. $0.05 \mathrm{mg} / \mathrm{kg}, 0.1 \mathrm{mg} / \mathrm{kg}, 0.5 \mathrm{mg} / \mathrm{kg}$ 及び $1 \mathrm{mg} / \mathrm{kg}$ 静注ではいずれの場合にも注射直後より $15 \sim 20 \mathrm{~mm}$ $\mathrm{Hg}$ の下降を呈したが排出液滴数には何らの変化も認められなかった。

(iii) $\mathrm{Cp}$ とAd の相互作用について

Cp. $0.5 \mathrm{mg} / \mathrm{kg}$ 静注後 $5^{\mathrm{m}}$ で Ad. $7 \mu \mathrm{g} / \mathrm{kg}$ を髅注したところ滴数恃殆んど增加を認めず又血圧む殆んど上 昇を示さなかった. 又 $\mathrm{Cp} .1 \mathrm{mg} / \mathrm{kg}$ 投与後 $10^{\mathrm{m}}$ で Ad. $7 \mu \mathrm{g} / \mathrm{kg}$ 静注の場合も血厌は殆んど变らなく、滴数も 初期の著明な增加を示さなかった。

(IV) Cp. と Caff. の相互作用について

Cp. $0.5 \mathrm{mg} / \mathrm{kg}$ 静注後 $10^{\mathrm{m}}$ で Caff. $40 \mathrm{mg} / \mathrm{kg}$ を静注すると滴数は僅が增加してのち直ちに旧に復し， 血圧も僅かな下降を示すのみであった， C p.を增量して $1 \mathrm{mg} / \mathrm{kg}$ 前投与後 $20^{\mathrm{m}}$ K Caff. $40 \mathrm{mg} / \mathrm{kg}$ を投与した 場合る前実験と同様の結果であった。

(V) Cp. と ACh. の相互作用について

Cp. $1 \mathrm{mg} / \mathrm{kg}$ 静注後 $20^{\mathrm{m}} \mathrm{K} \mathrm{ACh} .5 \mu \mathrm{g} / \mathrm{kg}$ を投与すると ACh. Kよる血生下降は Cp. を投与しない場合 の1/2となり，血王下降と併せて起る滴数增加はより明らかで，その後滴数間谝が增大したのち旧に復する。 Cp. 投与 $40^{\mathrm{m}}$ 後に ACh. $5 \mu \mathrm{g} / \mathrm{kg}$ を投与した場合もはぼ前述と同様の結果を示した。

(VI) Cp. と Hist. の相互関係について

Cp. $1 \mathrm{mg} / \mathrm{kg}$ 投与後 $10^{\mathrm{m}}$ あるいは $30^{\mathrm{m}}$ K Hist. $5 \mu \mathrm{g} / \mathrm{kg}$ を静注すると血仕は Cp. 投与前に示した值の約 1/2の下降度を示し，滴数は初期一過性に增加したのち直ちに間隔を增し比較的速やかに旧に復した。

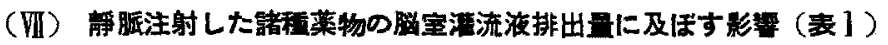

第 1 表. 股静脈内に注射した諸種薬物の灌流液排出量に及注す影響.

\begin{tabular}{|c|c|c|c|c|c|c|}
\hline Drug & Met & $\begin{array}{l}\mathrm{DO} \\
(/ \mathrm{kg})\end{array}$ & $\underset{\text { (min.) }}{\mathrm{T}}$ & & $\begin{array}{l}\text { Volume of Outflow within } 10 \text { minutes } \\
\text { in each Injection (cc/10min.) }\end{array}$ & M.V. \\
\hline $\begin{array}{l}d \text {-Tubocurarine } \\
\text { chloride }\end{array}$ & C & $\begin{array}{l}0.5 \sim 1 \mathrm{mg} \\
0.5 \mathrm{mg}\end{array}$ & $\begin{array}{r}1 \sim 10 \\
10 \sim 20 \\
1 \sim 10 \\
10 \sim 20\end{array}$ & $\begin{array}{l}1.31 \\
1.10\end{array}$ & 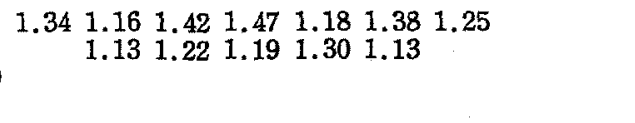 & $\begin{array}{l}1.31+ \\
1.19+ \\
1.10-\end{array}$ \\
\hline $\begin{array}{l}\text { Adrenaline } \\
\text { chloride }\end{array}$ & $\begin{array}{l}\mathrm{C} \\
\mathrm{A}\end{array}$ & $\begin{array}{l}7 \sim 10 \mu \mathrm{g} \\
10 \mu \mathrm{g}\end{array}$ & $\begin{array}{r}1 \sim 10 \\
10 \sim 20 \\
1 \sim 10 \\
10 \sim 20\end{array}$ & $\begin{array}{l}1.10 \\
1.16\end{array}$ & 1.201 .161 .191 .25 & $\begin{array}{l}1.18+ \\
1.16 \pm\end{array}$ \\
\hline $\begin{array}{l}\text { Acetylcholine } \\
\text { chloride }\end{array}$ & C & $\begin{array}{l}6 \sim 10 \mu \mathrm{g} \\
7 \mu \mathrm{g}\end{array}$ & $\begin{array}{r}1 \sim 10 \\
10 \sim 20 \\
1 \sim 10 \\
10 \sim 20\end{array}$ & $\begin{array}{l}1.08 \\
1.18\end{array}$ & 1.221 .18 & $\begin{array}{l}1.16 \pm \\
1.18+\end{array}$ \\
\hline $\begin{array}{l}\text { Caffeine } \\
\text { sodiobenzoate }\end{array}$ & $\begin{array}{l}\text { C } \\
\text { A }\end{array}$ & $\begin{array}{l}40 \sim 50 \mathrm{mg} \\
40 \mathrm{mg}\end{array}$ & $\begin{array}{r}1 \sim 10 \\
10 \sim 20 \\
1 \sim 10 \\
10 \sim 20\end{array}$ & $\begin{array}{l}1.20 \\
1.21\end{array}$ & 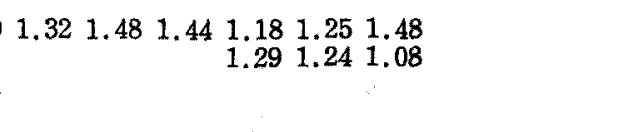 & $\begin{array}{l}1.33+ \\
1.20+ \\
1.21+\end{array}$ \\
\hline $\begin{array}{l}\text { Histamine } \\
\text { dihydrochloride }\end{array}$ & C & $\begin{array}{l}5 \sim 10 \mu \mathrm{g} \\
5 \mu \mathrm{g}\end{array}$ & $\begin{array}{r}1 \sim 10 \\
10 \sim 20 \\
1 \sim 10 \\
10 \sim 20\end{array}$ & $\begin{array}{l}1.21 \\
1.05\end{array}$ & $\begin{array}{r}1.28 \begin{array}{l}1.10 \\
1.18\end{array} \\
\end{array}$ & $\begin{array}{l}1.19+ \\
1.18+ \\
1.05=\end{array}$ \\
\hline Chlorpromozine & C & $\begin{array}{l}0.05 \sim 5 \mathrm{mg} \\
0.05 \sim 1 \mathrm{mg}\end{array}$ & $\begin{array}{r}1 \sim 10 \\
10 \sim 20 \\
1 \sim 10 \\
12 \sim 20\end{array}$ & $\begin{array}{l}1.11 \\
1.14\end{array}$ & 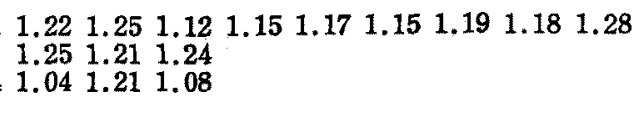 & $\begin{array}{l}1.16 \pm \\
1.23+ \\
1.11-\end{array}$ \\
\hline
\end{tabular}


以上のと括り本実験に使用した6種の薬物（Drug）の一定量（Do.）をそれぞれ静脈内に注射したとき，一 定時間 ( $\mathrm{T}$ ) 内の灌流排出液量 (Volume of Outflow) を測定し, 回数は間わず算術平均値を出し增量または 減量を(十)(一) で表現すると，（C）法に扔いて $d$-Tc. Caff. 投与後 $10^{\mathrm{m}}$ に著明な排出液の增量を認め Hist. 投与では僅かに増量の傾向をみたがその他の薬物では顕著な变化を認めなかった。

（A）法に拟いて著明な增量を認めることはなかった。

\section{考按}

著者は第 l 報11) 及び第II 報13) 飞括いてネコの脳室クモ膜下腔灌流実験（C法）と側脳室，第三脳室灌流実 験（A法）を試み，この方法で諸種の薬物を灌流液内に注入し，その呼吸，血圧に対する中枢性の影響による变 動を観察する方法を確立した. その際同時に描記した灌流液排出滴数の增加を幾つかの薬物に㧊いて見出した。 そのらち特記すべきことは高張食塩水を含め濃度の高いもの程その堌量が著明であり，しかも(C)法に和いて も同樣汇起きたことであり Ad. ACh. 及び蒸溜水は滴数の增加が認められなかったことで，著者はこの現象を濃 度の高い異張溶夜による浸透圧美に起因する脳の一過性の腫張又は浮腫によるるのと解した．即ち薬液の脳組織 に浸透しないるのに対しては畄細胞外液が灌流液内に挗張する為 c.s.f. が増加するすのであり脳組織に浸透し た薬液は脳組織自由水並びに結合水を血獎より移行させることにより絪腫張または浮腫をつくり二次的に脳室及 びクモ膜下腔を縮小し，灌流液排出滴数を增したものと考える。

灌流液排出量を規定するものは, 諸家の報告によれば, 呼吸, 血圧, 脳血流量, 脳膜血管の拻張縮少等の モ膜下腔又は脳室の容稓の変化又は c.s.f. の産生即ち, 分泌, 透析, 汇出又は再吸収等の c.s.f. の内容の変化 で, 灌流液排出量はクモ膜下腔と脳室の容皘の変化または c.s.f. 自身の增減に左右されるすのと考学る.

Ferris ${ }^{2)}$ は頭蓋を容馧の变らぬ固い容器とみなし, 此処に出入する血流を Plethysmograph 法によって 測定せんとし，首の周りに 60〜80 $\mathrm{mmHg}$ の王を加え春髄腹に㧴入した注射針を通じて液の動く割合を測定し これによって脳血流の状態を推定した。

Monro-Kellie の原理で知られると括り頭蓋は膨張しない固い容器であり加圧により頙部静脈流が停止すれ ぱ, 頭蓋内静脈の膨張によって c.s.f. が排除される筈であり,この場合脳圧の変化は頭蓋内への動脈流の変化

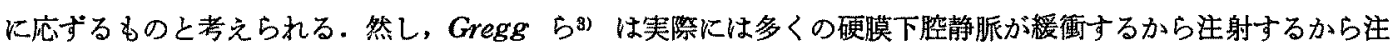

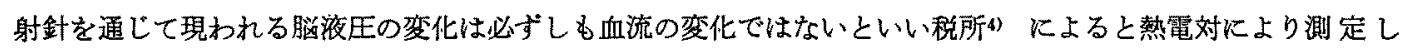

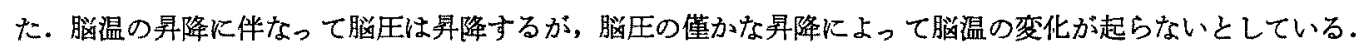

一方原田5) 14/15) は c.s.p. の流体力学的研究に打いて c.s.p. の動摇は脳血管容積の增減に因るもの c.s.f. の量及び脳春髄実質の容積の增減を考虑する必要はなく、このことは c.s.p. の曲線は脳血管容䄼曲線を意味す るものであるとしている. Bhattacharya \& Feldberg1) は生体脳室の灌流を行い Tubocurarine, Hist., Ad. を 静注した結果 Cisterna からの集液には大きな変化があったのに対し, Aqueduct からの集癛は何らの変化も起 らなかった.これらの Cisterna からの流出液の变化は Tubocurarine, Hist. を与光ることにより血压が下降

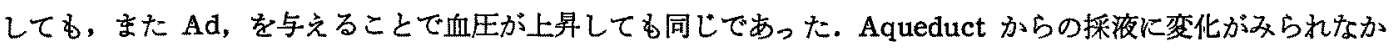
ったことは側脳室第三脳室ひいて第四脳室の脈絡膜 (以下 Choroid pl. と略す) からの c.s.f. の分泌を否定す る事実であり, Cisterna からの採液の変化は灌流組織に和けるっモ膜下沿の相対的容量の変化に因するすので 更にこれは(1)クモ膜下腔における c.s.f. 生成の変化, (2)血圧, 脳血流量から情結されるクモ膜下腔の容量の変 化あるいは，(3)脳膜血管の変化と考兄られ広範囲にわたって Cisterna からの採液の变化は中枢神経系の未梢 血管に対する反応に適合したことを意味していると説いた。

著者は（C）法及び (A) 法で d-Tc., Ad., ACh., Hist., Caff. 及び Cp.をそれぞれ体部静脈内に投与し 排出液滴数を観察した結果次のことを知った.

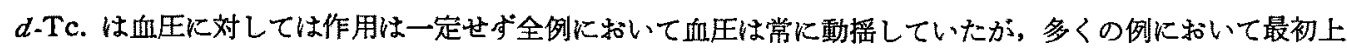
年し，しばらくして下降するといら二相性の变化を示した，滴数は注射後直ちに増加を示すが，血圧の動摇の如 何にかかわらず呼吸を開始すると規則的な排出を示した。このことは呼吸による不規則なクこ膜下腔の容筫の蹜 
少と血压とは関保のないクモ膜下腔に和ける c.s.f. の産生が関与しているるのと考えられる. 但しこの c.s.f. の産生は人工呼吸を開始して $d$-Tc. を2，3回射する時には起りにくくなっている．また（A）法に和いては滴 数は呼吸, 血王之は関係なく全く変動をみなかったが,このことは儧腷室, 第三脳室内における, c.s.f. の産生 機粠は全く働いていないことを意味しており，特に Choroid plexus からの分泌も全くないといらことも事実 である。

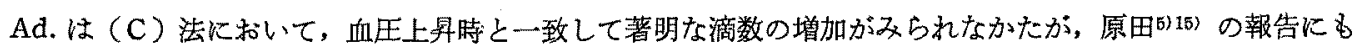
ある如く，体部血王の上界の為受動的汇脳血流量が増し，したがって脳血管の扯镸を来たして二次的にクモ膜下

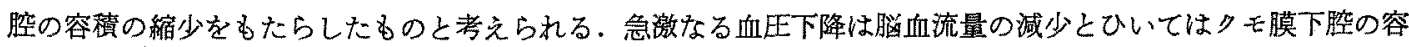
筫の減少をきたさせ滴数間隔の延長をみたことは Bhatlacharya \& Feldberg1) の報ずるところと同一であった がこれはクモ膜下腔の容磧の变動があくまです主体で c.s.f. の痤生は全く関与していないるのと解され，こ

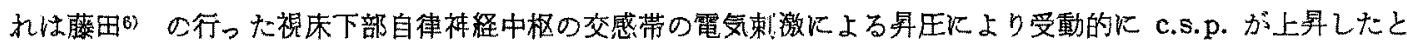
いらことと同意晹であるらと考党る。

ACh.は (C) 法において注射直後の著明な血圧下降々一致して滴数も減少し，しかも $10^{\mathrm{m}}$ 間の排出量は殆 んど增加しなかったことは体部血圧の下降をるたらした末梢血管拻張は脳血管でる著明でこ机によるクモ膜下腔

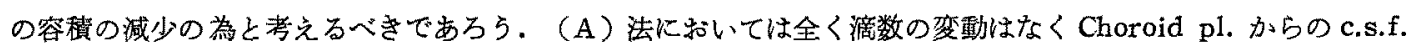
の産生も認められない。

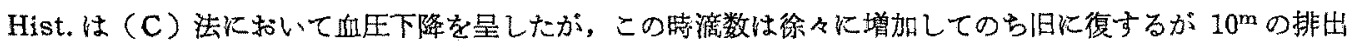
液量は僅が增加を示した。（A）法では全く滴数の变動をみせなかったことは，っも膜下腔内での c.s.f.の 産生が僅があったことで Hist.の脳血管に対する执張作用によりクモ膜下腔の容積が縮少した為にほかならな い. 脕所》〔とよれば Hist. は媨血流を增大せしめ脳圧を上昇せしめるという.

一方 Caff. は税所4) に上れば静注で比较的大量では脳血流の增大及び c.s.p. の上界を来たすとするが， （C）法に和いて Caff. $40 \mathrm{mg} / \mathrm{kg}$ の静注は著明な血圧の下降をるたらしたが，この下降と一致して著明な滴数 の增加をみたのち、これは次第に元の間隔に恢復した。1 $10^{\mathrm{m}}$ 間の排出量に著明な增加を認めたことはCaffの脳 末梢血管に対する直接の拻張作用によるタモ膜下胫の容積の縮少と加兄て, 脳膜血管の透過性の变化に上る

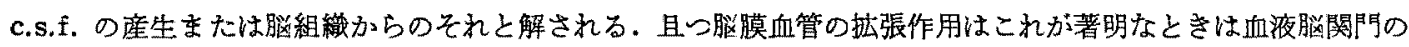
変化をもたらし，c.s.f. と血漿の化学的組成の変動を来たすことにより漫透区差が出来 c.s.f. の痤生をもたら すのであ万う.

Cp.を（C）法で投与すると少量では血王下降に一致して滴数の增加があり，又すぐ間隔が延長し再び元の 状態になった。このことは脳血管が最初一過性に生張し, ただちに体部血王下降に影響され脳血流量が減少しっ モ膜下腔が元に恢復するためであろう。Cp. 大量では初期の脳血管の拡張が起らず滴数の率動は殆えど起らなか った。白琵16)17) は C p.を猫の頚動脈内に注射すると血王は急速に下降するのに対し血流量は一過性に著明に增 加するが，その後は血圧の下降と平行して血流量の减少を来たすと報じている．即ちCp.の脳血管に対する直接 作用はむしろ拆張的で血流量を增するのである. 白跭16) は $1 \mathrm{mg} / \mathrm{kg}$ の静注で血流量の減少をみとめ体部血压下

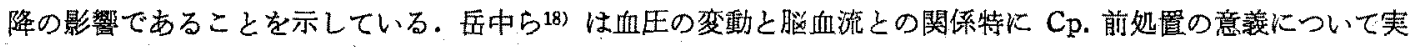
験し，岳中の方法に従って脳血流に及ぼす諸程薬物の影響について検討したが，その際薬物の脳血管床に対する

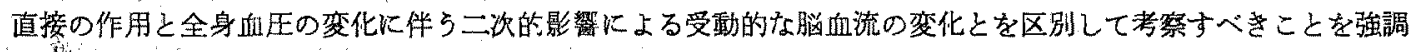
した。更に供血又性脱血により上年又は下降した血圧は甚たしく動播し不安定であるが Cp.前処置によりかかる 動摇は全く消失したと報じている.著者も（C）法において Ad., ACh., Caff. 及び Hist.をCp. 前処固のもと に注射したところ, Hist.を除いて他は全て血王の変動も抑制され掂数る变動が僅少となった. Hist.は流数が投 与直後著明な增加を示した. 即ち脳血管に対する薬物の作用は C p. に上り拮抗されるるのである.

以上を総括すると渡数の变化即ら c.s.p. を左右すり第 1 の要素“クモ膜下腔の容積の変化”は脳血流量に

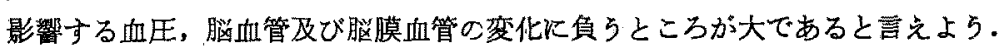

又第 2 の要素は “ c.s.f. の産生，吸収”の点である. 著者の使用した蒋物は循環系を介して Choroid pl- 
exus に対する分泌促進的な作用はない．しかる（C）法で排出量の絶対值が增加したのは $d$-Tc. と Caff. のみ で Hist. に和いて僅かな堌量を認めた。このととは前記第1の要素以外飞 c.s.f. の産生をらながすことが考克

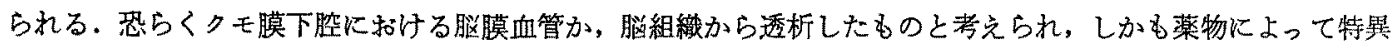

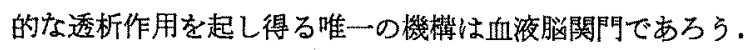

\section{まとぬ}

ネコの脳室, クモ膜下腔灌流実験 (C法) 及び側脳室, 第三脳室灌流実験 (A法)を行い, $d$-Tubocurarine Adrenaline, Acetylcholcholine, Histamine, Caffeine 及び Chlorpromazine をそれそれれ股静脈より注射し 血圧及び灌流液排出態度を滴数で観察した．（C）法では血王の変動にとるなって夫ム滴数の変動が認かられ， $d$-Tubocurarine, Histamine, Caffeine に括いて $10^{\mathrm{m}}$ の排出量加增加するのを観察し，一方 (A) 法に括いて は全く滴数の変動, 排出量の增加を認めなかった.

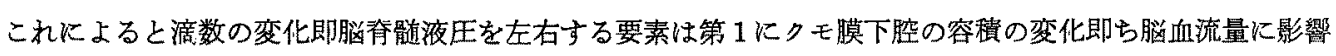

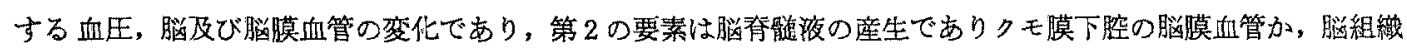
からの透析によるもので Choroid plexus からの分泌は考克られない.

稿を終るに臨み終始御琶篤なる御指導, 御校閲を睗った恩師小林龍男教授に心から感㴬を捧け゚ると共に村山 智講師, 久我㫪郎博士の御指導に梁く感謝致します.

\section{文献}

1) Bhattacharya B. K. \& Feldberg W. : Brit. J. Pharmacol, 13 ; 156 (1958).

2) Forris : Arch. Neurol. Psychiat : 46;377 (1941).

3) Gregg \& Shipley : Fed. Proc. 3 ; 144 (1944).

4) 税所厚：日薬理誌 $48: 100$ (昭27).

5) 原田均：福岡医誌30 978 (昭10).

6）藤田碩：大阪医誌 $1,2,1$ (昭29).

7) 黑津敏行：脳研究 3, 39 (1949).

8) Weed L. H. \& Cushing H. : Amer. J. Physiol. 36, 77 (1915).

9) Dixon W. F. \& Halliburton W. D. : J. Physiol. 47, 215 (1913).

10) Woollam, D. H. M. \& Millen, J. W. : The Cerebrospinal Fluid Production, Circulation and Absorption ; Ciba Foundation Symposium, 124, 1958, London, Churchill.

11）平島毅：日薬理誌, 脳空クモ膜下腔灌流実駼による中权神経系に関する薬理学的研究(第 1 報) 58,189 (1962).

12）平島毅：同上(第 2 報) 58,203 (1962) .

13) Jasper, H. H. \& Ajmone-Marsan, C. : A stereotaxic atlas of the diencephalon of the cat. The National Research Council of Canada, Ottawa (1954).

14）原田均：福岡医誌30，4,872（昭10）.

15）原田均：福岡医誌30, 4, 1023 (昭10).

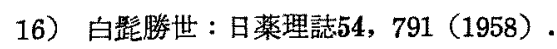

17) 白䇟勝世：同上54，839 (1958).

18）岳中典男: 松永行雄, 池田一郎, 横田康 : 日薬理誌54, 734（1958）. 